\title{
TRANSMUTACJA UTOPII \\ „NOWOCZESNA ALCHEMIA” I NAUKA W MIRANDZIE ANTONIEGO LANGEGO
}

\author{
ALEKSANDER WÓJTOWICZ*
}

„Dopóki człowiek jest półczłowiekiem, jak to mamy po dzień dzisiejszy, dopóty nie nadejdzie regnum humanum", prognozował Antoni Lange w komentarzu do Mirandy (1924). W słowach tych pobrzmiewa dylemat, który niczym cień towarzyszył literaturze utopijnej od czasu, gdy oświeceniowa „desakralizacja raju” przeniosła problem zła z wymiaru metafizycznego do historycznego, zachęcając tym samym pisarzy i filozofów do tworzenia coraz śmielszych wizji idealnego ustroju ${ }^{1}$. Od tej chwili w ich koncepcjach wyraźniej poczęły zaznaczać się echa „utopistycznego sporu na temat podmiotowości”, który sprowadzał się do pytania: „Czy utopia proponuje radykalne przekształcenie podmiotowości zakładane przez większość rewolucji, mutację ludzkiej natury i narodziny zupełnie nowych istot, czy może jednak utopijny impuls jest już wpisany w ludzką naturę?"’

Nowoczesność, która odziedziczyła te rozterki po wcześniejszych epokach, usiłowała rozwikłać je na własny sposób. I jakkolwiek nie zdołała uchylić wspomnianej alternatywy, to ugruntowała wiarę, że droga ku stworzeniu „nowego człowieka" wiedzie przez pakt pomiędzy nauką i techniką. Tymczasem Lange, inaczej niż większość mu współczesnych, był przekonany, że jest to rozwiązanie błędne. Dał temu wyraz w Mirandzie, którą uważał za swoisty eksperyment myślowy, mający na celu ,zbadanie warunków, w jakich możliwe by było stworzenie społeczności doskonałej"3. Był to, dodajmy, eksperyment zanurzony w aurze mitologii wczesnego modernizmu, nawiązujący do ezoteryki i wzorców orientalnych, przeciwstawianych krytycznie ocenianej kulturze europejskiej. ${ }^{4}$ Jego rdzeń

* Aleksander Wójtowicz - dr, IFP UMCS w Lublinie.

1 A. Lange, Przedmowa do wydania drugiego [w:] W czwartym wymiarze, Kraków 2003, s. 6.

${ }^{2}$ F. Ja meso n, Archeologie przyszłości. Pragnienie zwane utopiq i inne fantazje naukowe, przeł. M. Płaza i in., Kraków 2011, s. 201.

${ }^{3}$ A. Lange, Przedmowa do wydania drugiego, op. cit.

${ }^{4}$ Por. D. Trześnio ws ki, Chińskie fascynacje Antoniego Langego [w:] Bez antypodów?: zbliżenia i konfrontacje kultur, red. B. Mazan, Łódź 2008, s. 125-145; P. Woj c i e c h ow s ki, Lo- 
stanowiła koncepcja, która - przynajmniej na pozór - radykalnie odbiegała od wizji ówczesnych utopistów, snujących marzenia o całkowitym przekształceniu natury człowieka. Jednak z dzisiejszej perspektywy Miranda wydaje się być nie tylko rezultatem antymodernizacyjnego impulsu, lecz również - a może nawet przede wszystkim - utworem zanurzonym w atmosferze nowoczesnych sporów na temat postępu cywilizacyjnego oraz roli techniki w tym procesie. Co więcej, zaznaczają się w nim echa wstrząsów i transformacji, jakie zachodziły w dyskursach nauk ścisłych u progu dwudziestego stulecia.

„Wyjątkową, charakterystyczną tylko dla utopii właściwością jest jawna intertekstualność - niewiele jest form literackich, które by równie nachalnie polemizowały ze sobą nawzajem", pisał Frederic Jameson, komentując złożone związki pomiędzy tekstami należącymi do tego gatunku. W Mirandzie cecha ta zaznacza się w sposób wyjątkowo wyraźny, bowiem powieść została pomyślana jako modyfikacja koncepcji zawartych w Mieście Słońca Tomasza Campanelli. Trudno jednak oprzeć się wrażeniu, że pod pozorem korekty idei włoskiego pisarza Lange poprawia pomysły współczesnych mu utopistów.

Polemiczna intencja przesądziła o kompozycji tekstu, który osnuty jest wokół schematów charakterystycznych dla paradygmatu utopijnego obowiązującego do połowy XVIII wieku ${ }^{6}$. Decydując się na podjęcie dyskusji z tak odległą w czasie wizją, pisarz musiał sięgnąć po rozwiązania pozwalające zaprowadzić bohatera na Taprobne - wyspę, którą kilkaset lat wcześniej odwiedził Sternik z Genui. Z pomocą przyszła mu charakterystyczna dla tego gatunku narracja podróżnicza wraz z jej węzłowymi punktami: żeglugą po niebezpiecznych wodach, katastrofą statku, cudownym ocaleniem, przybyciem na wyspę oraz - wreszcie - spotkaniem jej tajemniczych mieszkańców.

„Czy jesteście bogowie, czy ludzie?” - zapytywał Jan Podobłoczny, przypatrując się obywatelom Suriawistu, których doskonałość rychło uprzytomniła mu, że znalazł się w ,,szczęśliwej krainie, gdzie urzeczywistniły się wszystkie ideały społeczne"' . Pierwsze zetknięcie z utopią stało się pretekstem do opisania doświadczenia radykalnej inności, od samego początku relacjonowanego za pomocą wrażeń zmysłowych; sprawiające wrażenie idealnych pejzaże, smaki oraz zapachy wprowadzały atmosferę, w której bohater stopniowo zatracał się, nie mogąc precyzyjnie określić granicy pomiędzy snem a jawą. Na pierwszych stronach powieści istotną rolę odgrywa również impuls intertekstualny, wyładowujący się przede wszystkim w zarysowaniu zmian, jakie w ciągu kilkuset lat zaszły w Grodzie Słońca. Modyfikacja urbanistycznych i architektonicznych rozwiązań

gos, byt, harmonia. Antoniego Langego czytanie kultury, Lublin 2010, s. 199-217; J. Tu c z y ń s k i, Antoni Lange [w:] Motywy indyjskie w literaturze polskiej, Warszawa 1981.

${ }^{5}$ F. Ja me so n, op. cit., s. 2.

${ }^{6}$ Por. B. B aczko, Hiob, mój przyjaciel: obietnice szczęścia i nieuchronność zła, przeł. J. Niecikowski, Warszawa 2001, s. 123 i nast.

7 A. Lan ge, Miranda, Kraków 2002, s. 19 i 24. 
zaproponowanych przez Campanellę, sporządzona została z dużym umiarem, bowiem jej nadrzędnym celem jest podkreślenie, że brakuje tutaj jakichkolwiek śladów industrializacji, która w ciągu jednego stulecia nieodwracalnie przeobraziła oblicze kontynentu europejskiego. Jest to jeden z węzłowych punktów w utopijnym dyskursie Langego; manifestacyjne odrzucenie wytworów techniki ma być sygnałem istnienia innej, alternatywnej ścieżki rozwoju cywilizacyjnego. Logikę jego wywodów można rozpatrywać w ramach siatki opozycji pomiędzy Europą a Orientem, rozszczepiającą się na szereg przeciwstawień (technika-duchowość, egoizm-altruizm, powierzchnia-głębia), lecz wydaje się, że taka strategia nie do końca wyjaśnia akcenty, jakie dochodzą do głosu w opisie dziejów Miasta Słońca.

Historia tej utopii okazała się przede wszystkim historią duchowych upadków i wzlotów. Podczas rozmów z miejscowymi dostojnikami Podobłoczny dowiadywał się, że organizacja idealnego ustroju, którą przedstawił Campanella, nie zdała egzaminu. „Nasi mędrcy-organizatorzy”, mówi jeden z nich, ,popełnili błąd, przypuszczając, jakoby można stworzyć społeczeństwo, oparłszy je wyłącznie na zasadach wysnutych z czystego rozumu, a pominąwszy znaczenie popędów, instynktów, namiętności i wszystkich słabych stron natury ludzkiej, dla których rozum nie jest dostatecznym hamulcem"». Wszystkie one eksplodowały w momencie zniesienia dotychczasowych ograniczeń, rozsadzając ład i powodując eskalację chaosu, który doprowadził do degeneracji Republiki, a ostatecznie - do utraty niepodległości.

Inscenizacja upadku Miasta Słońca, które zapadło się pod ciężarem własnych iluzji, stała się dla pisarza punktem wyjścia do polemiki z aksjomatami, jakie patronowały kolejnym pokoleniom utopistów. Rozkładając na czynniki pierwsze ich wizje, odnajduje w nich ten sam ,słaby punkt” - optymistyczną wiarę w dobro człowieka. Sceptycyzm ten nie przekreśla jednak samej idei utopii, lecz godzi w jej dotychczasowe fundamenty, nazbyt wątłe, aby udźwignąć wspaniały gmach przyszłego społeczeństwa. Warto zaznaczyć, że podobne wnioski odnaleźć można w napisanych w latach dwudziestych utworach Antoniego Słonimskiego Torpedzie czasu i Wieży Babel. Zawierają one dwie odsłony charakterystycznego dla literatury nowoczesnej konfliktu pomiędzy wybitną jednostką (developperem) a ogółem, który nie jest w stanie pojąć doniosłości snutych przezeń projektów ${ }^{9}$. Ich fiasko to nie tylko indywidualna tragedia, lecz także klęska całej ludzkości, niepotrafiącej przekroczyć progu dzielącego ją od wspaniałego świata

8 Ibidem, s. 41.

9 Według Marshalla Bermana developper to ,jedno z wcieleń nowoczesnego człowieka czynu. Źródłem jego siły jest idea doskonałego społeczeństwa przyszłości, którego organizacja przewyższa wszystkie znane dotychczas formy, zaś mechanizmem napędowym podejmowanych działań - hasło modernizacji utożsamianej z wdrażaniem w życie idei postępu". Por. M. B e r m an, „Wszystko, co stałe, rozpływa się w powietrzu”. Rzecz o doświadczeniu nowoczesności, przeł. M. Szuter, Kraków 2006, s. 85 i nast. 
przyszłości. O ile jednak Słonimski ograniczał się do podkreślania tragicznej bezradności swoich bohaterów, o tyle Lange odrzucał myśl o kapitulacji i proponował rozwikłanie tego dylematu za pomocą rozwiązań z pogranicza alchemii i konwencji science fiction.

Na gruzach wcześniejszej utopii mieszkańcy Miasta Słońca zbudowali społeczeństwo pozbawione dotychczasowych mankamentów. Kluczem do tego przedsięwzięcia stało się Nirwidum - tajemniczy „,pierwiastek” odkryty w laboratorium przez mędrca, który „do samego rdzenia przeniknął budowę materii i związanej z nią niepodzielnie energii" ${ }^{10}$. Pozwoliło to na stworzenie doskonałych gmachów, pojazdów i narzędzi, dzięki którym Miasto Słońca stało się zaczątkiem nowej, zwróconej ku przyszłości cywilizacji. Właściwości Nirwidum przywodzą przy tym na myśl tropiony przez średniowiecznych alchemików „kamień filozoficzny"; umożliwiało ono przemianę ołowiu w złoto, czyli - mówiąc inaczej - transmutację. Ale utopijna fantazja Langego szła o krok dalej: analogiczna „transmutacja" stała się narzędziem służącym stworzeniu nowego człowieka.

Proces ten został wyjaśniony przez odwołanie do pojęć z zakresu popularnej wówczas metapsychiki. ,Jest w nas człowiek zewnętrzny, mało co różny od zwierzęcia, wieczny ludożerca”, tłumaczył Podobłocznemu jeden z mędrców, „oraz człowiek wewnętrzny, jego duch nieśmiertelny, jego Jaźń wiekuista - nieraz zupełnie obcy tej gruboskórnej powłoce, w której duch mieszka" ${ }^{11}$. Wychodząc z takiego założenia, tamtejsi uczeni poczęli poszukiwać sposobu na unicestwienie pierwszego oraz unieśmiertelnienie drugiego. Rozwiązanie tego problemu podsunęły im seanse spirytystyczne, w czasie których z „,człowieka doczesnego” wydobywał się „człowiek astralny”, „wewnętrzne, doskonalsze, wiekuiste Ja”" Dzięki urządzeniom wykorzystującym niezwykłe właściwości Nirwidum udało im się dokonać transformacji człowieka w ,istotę fluidyczną”, utrwalaną przy pomocy tajemniczego pierwiastka. Jednak ,aby te widma astralne mogły się niejako uczłowieczyć, musi przedtem nastąpić dematerializacja zupełna człowieka; widmo zaś zostaje wyzwolone, zwulkanizowane i utrwalone" ${ }^{13}$. W ten sposób dokonywała się swoista „transmutacja społeczeństwa” - miejsce niedoskonałych ludzi zajmowały doskonałe ,astrale”.

Metoda ta potwierdzała intuicje Podobłocznego, który już wcześniej prowadził analogiczne eksperymenty w przekonaniu, że tkwi w nich klucz do wyjaśnienia natury człowieka. Sięgając po tego rodzaju uzasadnienia, Lange nawiązywał do popularnego w owym czasie spirytyzmu, który miał równie wielu nieprzejednanych wrogów, co gorących entuzjastów. Pierwsi, do których zaliczał się choćby Bruno Winawer, widzieli w nim emanację naiwnych tęsknot i naukowe

\footnotetext{
${ }^{10}$ A. Lange, Miranda, op. cit., s. 45.

${ }^{11}$ Ibidem, s. 43.

12 Ibidem, s. 44.

13 Ibidem, s. 45.
} 
szalbierstwo, drudzy natomiast wynosili do rangi jednej z najbardziej doniosłych poznawczo tendencji początku dwudziestego stulecia. Powoływali się przy tym na głośne wówczas w Europie badania Piotra Lebiedzińskiego, usiłującego badać przy użyciu metod naukowych zjawisko materializacji oraz ektoplazmę. Eksperymenty podejmowane w czasie seansów spirytystycznych miały wówczas zresztą szeroki oddźwięk. Były pożywką dla prasy codziennej oraz elektryzowały ówczesne elity społeczne i artystów, takich jak Maria Pawlikowska-Jasnorzewska, Witkacy, Stefan Grabiński czy - wreszcie - Lange ${ }^{14}$.

Wyraźny ślad tych zainteresowań zawierają jego opowiadania z tomu W czwartym wymiarze (1914). Obracają się one w kręgu nauki i metapsychiki, obejmując przy tym szeroką wiązkę motywów, takich jak hipnoza, zjawy, sobowtóry oraz próba zapanowania nad czasem i procesami biologicznymi. Ten różnorodny kalejdoskop fabuł inspirowany był fascynacją spirytyzmem oraz wsparty na przekonaniu, że najnowsze odkrycia naukowe mogą stać się narzędziami umożliwiającymi zrozumienie zjawisk nie zawsze słusznie uznawanych za paranormalne. Sam pisarz po latach skłonny był zresztą postrzegać te teksty jako swoistą antycypację zagadnień, które będą zaprzątać umysły uczonych w najbliższych dekadach ${ }^{15}$, lecz trudno oprzeć się wrażeniu, że interesowały go nie tyle perspektywy rozwoju wiedzy, co raczej domniemania na temat poznawczego potencjału ,wiedzy tajemnej”. Wskazuje na to choćby opowiadanie Eksperyment, w którym zafascynowany hipnozą bohater przeprowadzał badania na nowo narodzonym dziecku. W trakcie seansu nawiązał kontakt $\mathrm{z}$,,niepojętą istotą [...] z dalekich niebios, ze sfery, po której krąży sześćset sześćdziesiąt sześć drobnych planet"16, dla której pobyt na Ziemi był karą za grzechy popełnione na gwieździe Cerera. Utkany z kulturowych odniesień obraz nie stał się jednak impulsem do dociekań stricte naukowych, lecz pretekstem do zarysowania wizji społeczności, której udało się przezwyciężyć materię i zbudować świat, gdzie nie ma „walki, przeciwieństw, załamań”17.

Z opowieści tej wyłaniają się zręby utopii, która w Mirandzie sprowadzona została na Ziemię i osadzona na samotnej wyspie pośród wód Oceanu Indyjskiego. Są to jednak zalążki kiełkujące na gruncie spekulacji spirytystycznych i podsycane marzeniami o idealnej harmonii, jaka miałaby panować w nieznającym ludzkich trosk „czwartym wymiarze”. Mieszkające tam istoty karmiły się powietrzem, komunikowały za pomocą telepatii, przenikały wzrokiem dalekie zakamarki wszechświata, zaś ich życie przebiegało pod znakiem kontemplacji. Lange - inaczej niż ówcześni pisarze spod znaku science fiction - nie troszczył

${ }_{14}$ Zob. A. Mikołejko, Dlaczego zjawa ma ciało? Spór o istotę materializacji na przełomie XIX i XX w. [w:] Ucieleśnienia. Ciało w zwierciadle wspótczesnej humanistyki, red. A. Wieczorkiewicz, J. Bator, Warszawa 2007.

${ }^{15}$ A. Lang e, Przedmowa do wydania drugiego, op. cit., s. 5 i nast.

${ }^{16}$ A. La n ge, Eksperyment [w:] W czwartym wymiarze, op. cit., s. 59.

${ }^{17}$ Ibidem, s. 62. 
się przy tym o opis wynalazków i ułatwień technologicznych, bowiem te były dlań czymś nieistotnym w obliczu spraw o wiele donioślejszych. Dlatego właśnie na pierwszy plan wysunął gnostycką z ducha koncepcję grzechu, który był równoznaczny z upadkiem ducha w skażony materią świat. Nietrudno zauważyć, że do głosu dochodzą tutaj te same wątki, które w o wiele bardziej wyrazisty sposób wybrzmiały w napisanej kilkanaście lat później Mirandzie. Natomiast w szerszym wymiarze opowiadanie to wydaje się symptomatyczne dla pierwszej fazy nowoczesności, kiedy pod wpływem zdobyczy nauki niepewna swojej kondycji epoka usiłowała na nowo sporządzić własny bilans duchowy.

Przewartościowania te były konsekwencją opisanego przez Maxa Webera procesu „odczarowania świata”. Dominujący wówczas tryb opowieści o nauce zwykł identyfikować je z kumulatywną wiązką odkryć naukowych, za sprawą których dokonywało się stopniowe zwycięstwo racjonalizmu i desakralizacji. Ta optymistyczna i niepozbawiona triumfalistycznych akcentów wizja rychło doczekała się różnych kontrnarracji, których fala wzbierała przez całe dziewiętnaste stulecie wraz z rosnącą popularnością mesmeryzmu, spirytualizmu, teozofii i hermetyzmu. Jej apogeum nastąpiło na przełomie dziewiętnastego i dwudziestego stulecia, kiedy szeroko pojmowany „nowy okultyzm” (new occultism) stał się alternatywą nie tylko dla religijnej ortodoksji, lecz także dla scjentyzmu ${ }^{18}$. Stawką podejmowanych przez jego rzeczników poszukiwań było jednak nie tylko ponowne „zaczarowanie świata”, bowiem ich ambicje sięgały niekiedy o wiele dalej. Dotyczyło to zwłaszcza zwolenników „nowoczesnej alchemii” (modern alchemy), których dzieje zostały opisane przez Marka S. Morrisona w książce Modern Alchemy. Occultism and the Emergence of Athomic Theory. W odróżnieniu od poprzedników z minionych stuleci, skupionych zazwyczaj w nieformalnych stowarzyszeniach, rekrutowali się oni ze środowisk bliskich nauce i działali w sposób oficjalny. Zrzeszeni byli w różnorodnych organizacjach, z których największą sławę zyskało założone w 1912 roku w Londynie „Alchemical Society". Jego członkowie organizowali cykliczne spotkania, w których uczestniczyli zarówno okultyści, jak i wywodzący się ze środowisk akademickich chemicy. Łączyło ich przekonanie, że pomiędzy dawną „,wiedzą tajemną” a najnowszymi odkryciami nauki zarysowuje się coraz wyraźniej uchwytny związek. Wychodząc z takiego założenia, nawoływali do renegocjacji granic pomiędzy okultyzmem i nauką oraz podnosili pytania o „kosmologiczne, duchowe i etyczne wnioski, jakie można wyciągnąć z rozkwitu nauki atomowej"19.

Na przełomie stuleci ich zainteresowanie przykuły zwłaszcza dwa odkrycia. W 1895 roku Wilhelm Roentgen natrafił na nieznany dotychczas typ promie-

${ }_{18}$ Por. A. Owe n, The Place of Enchantment: British Occultism and the Culture of the Modern, University of Chicago Press, Chicago 2004, s. 24 i nast.

${ }_{19}$ M. S. Morris son, Modern Alchemy. Occultism and the Emergence of Atomic Theory, Oxford University Press 2007, s. 49. 
niowania, który ze względu na tajemnicze właściwości ochrzcił mianem ,promieniowania X". Natomiast parę lat później Ernst Rutherford i Frederick Soddy w trakcie badań prowadzonych nad radem udowodnili, że jego radioaktywne elementy ulegają dezintegracji, uwalniając przy tym radioaktywność i równocześnie transformując się w elementy inne. Według adeptów „,nowoczesnej alchemii” pierwsze odkrycie udowodniło istnienie zjawisk, które mogły podważyć panującą dotychczas wiedzę o siłach działających w naturze, natomiast drugie dowiodło, że opisywana w legendach idea transmutacji nie jest filozoficzną mrzonką, lecz zjawiskiem, które można osiągnąć na drodze eksperymentów naukowych. Entuzjazm ten znalazł zresztą odzwierciedlenie w ówczesnej literaturze popularnej, a zwłaszcza w powieściach grozy, których twórcy pospiesznie adaptowali wspomniane odkrycia na potrzeby konstruowanych przez siebie fabuł. Bram Stoker w powieści Klejnot siedmiu gwiazd (The Jewel of Seven Stars) tajemnicze wydarzenia obserwowane podczas prac archeologicznych prowadzonych w Egipcie tłumaczył promieniowaniem radonu, zaś Rider Haggard wokół właściwości tego pierwiastka osnuł powieść Ayesha. Powrót Onej (Ayesha: The Return of She, 1904-1905). Nie były to zresztą przypadki incydentalne, lecz symptomy przemian kulturowych, których kontury zarysowywały się coraz wyraźniej u progu dwudziestego stulecia.

Pracom ówczesnych naukowców niczym cień towarzyszyły domysły zwolenników ,nowoczesnej alchemii”. Odkrycia pierwszych stanowiły pożywkę dla drugich, którzy adaptowali je na potrzeby własnych teorii i stawiali pytania o duchowe oraz etyczne konsekwencje osiągnięć dokonanych w laboratoriach. Domysły te zataczały zresztą coraz szersze kręgi, sprawiając, że nawet ,religijni sceptycy poczęli się zastanawiać, czy alchemicy nie pojęli w naturze materii czegoś, co przeoczyła dziewiętnastowieczna nauka"20. Atmosfera taka zachęcała do stawiania pytań o zasadność granic wytyczonych między dyskursami naukowymi. Postępujące zacieranie różnic pomiędzy fizyką a chemią stało się dla alchemików pretekstem do podważania obowiązujących dotychczas podziałów oraz impulsem do stawiania postulatów wnoszących o uznanie naukowego charakteru reprezentowanej przez nich dziedziny.

Intensywność tych wystąpień podsycały wypowiedzi ówczesnych uczonych, którzy, definiując specyfikę prowadzonych przez siebie poszukiwań, chętnie posługiwali się metaforyką ,pogranicza” (borderland), podkreślając w ten sposób złożony charakter przekształceń, jakie dokonywały się w tym czasie w dyskursach nauk ścisłych ${ }^{21}$. Co więcej, nie stronili od podkreślania transcendentalnego wymiaru podejmowanych przez siebie przedsięwzięć; w tekście Alchemia $i$ chemia Soddy w entuzjastycznym tonie podkreślał, że jest wybrańcem, któremu dane zostało spełnić marzenia chemików wszystkich czasów - osiągnąć

\footnotetext{
20 Ibidem, s. 12.
}

21 Ibidem, s. 98. 
naturalną transmutację $e^{22}$. W ślad za takimi deklaracjami szły zanurzone w aurze myślenia mitologicznego domysły o istnieniu swoistej ,,atomowej Utopii”, starożytnej cywilizacji, która posiadła horyzonty wiedzy podobne do tych, jakie dopiero otwierały się przed współczesnymi ${ }^{23}$. I choć większość uczonych zachowywała dystans wobec tego rodzaju spekulacji, to nawet nieporównywalnie bardziej wstrzemięźliwy Rutherford dla opisania istoty swoich badań sięgał po efektowną analogię $\mathrm{z}$ alchemią ${ }^{24}$.

Echa tych zjawisk wyraźnie zaznaczają się w powieści Langego. Wybrzmiewające w niej wątki spirytystyczne miały stanowić alternatywę dla krytycznie ocenianego rozwoju technologicznego, lecz trzeba podkreślić, że wsparte zostały na pomysłach, które tkwiły korzeniami w specyfice ówczesnych odkryć naukowych. Poszukiwany przez alchemików „kamień filozoficzny” pisarz zastąpił „maszyną maszyn”25, umożliwiającą wytwarzanie i gromadzenie Nirwidum, czyli najmniejszej cząstki materii. O naukowej genezie tego konceptu przekonuje umieszczenie go w kontekście ówczesnych badań fizyki atomowej; w 1897 roku Joseph John Tomphson odkrył elektron i przedstawił pierwszy model struktury atomu (skorygowany w 1909 i 1913 przez Nielsa Bohra), w 1919 Rutherford proton, zaś w 1932 James Chadwick - neutron. Spekulacje Langego wpisywały się zatem w horyzont bliski poszukiwaniom ówczesnej fizyki, dzieląc z nią nadzieję na rychłe znalezienie cząstki materii, z której zbudowany jest cały wszechświat.

Ambicje naukowe splatały się jednak w Mirandzie z marzeniami bliskimi „nowoczesnej alchemii”. Znalazły one ujście w snutych od wieków domysłach na temat transmutacji, której celem miało być rozbicie badanego materiału na cząstki podstawowe (prima materia), a następnie wytworzenie z nich (przy użyciu „kamienia filozoficznego”) substancji szlachetniejszej². Odkrycia fizyków i chemików w pierwszych dekadach dwudziestego wieku zachęcały zwolenników okultyzmu i alchemii do głoszenia tezy, że świat znajduje się u progu odkrycia procesu mogącego stać się remedium na wszelkie trapiące współczesność bolączki. Temperatura ówczesnej „,transmutacyjnej euforii”"27 osiągnęła apogeum w drugiej dekadzie minionego stulecia, skutkując szeregiem nieweryfikowalnych hipotez, niespełnionych proroctw i zawiedzionych nadziei (na przykład na pro-

${ }^{22}$ Zob. R. E. S c love, From Alchemy to Atomic War: Frederick Soddy's „Technology Assesment” of Atomic Energy, „Science, Technology \& Human Values” 1989, nr 2 (vol. 14), s. 168.

${ }^{23}$ Ibidem, s. 174.

${ }^{24}$ Zob. E. Rutherford, Newer Alchemy. Based on the Henry Sidgwick Memorial Lecture Delivered at Newnham College Cambridge November 1936, Cambridge University Press 1937.

25 A. Lange, Miranda, op. cit., s. 75.

${ }^{26}$ Por. W. Fe re n c, Na poczqtku była filozofia...”. Od alchemii do chemii, Lublin 1998, s. 92 i nast.; M. S. Morris son, op. cit., s. 115-120; R. Bu gaj, Hermetyzm, Wrocław 1991, s. $217-$ 237.

${ }^{27}$ M. S. Morriso n, ibidem, s. 124. 
dukcję sztucznego złota). Wydaje się, że odcisnęła również piętno na specyfice pomysłów Langego, który w utopijnej powieści spożytkował ją dla opisania dwóch wymiarów transformacji: materialnego i duchowego.

Nirwidum, swoista alchemiczna prima materia, uszlachetniona została przez działanie tajemniczej maszyny, której sekretu pilnie strzegli władcy Miasta Słońca. Wytwarzana bez żadnych ograniczeń, służyła do wznoszenia spektakularnych budowli oraz zaspokajania wszystkich potrzeb mieszkańców. W tym aspekcie utopijna fantazja pisarza ma charakter totalizujący, bowiem za jednym zamachem rozwiązuje wszystkie dylematy, nad których rozstrzygnięciem głowiły się kolejne pokolenia utopistów. Dzięki rozwojowi nauki, która przeniknęła zagadkę budowy wszechświata, powstał ustrój doskonały, niezagrożony niebezpieczeństwami i wstrząsami, jakie nieustannie nękały Europejczyków. Pod tym względem Miranda jest poniekąd dzieckiem swojego czasu i wykazuje spore podobieństwa z licznym rodzeństwem utworów, jakie wyszły spod pióra nowoczesnych utopistów w pierwszych dekadach dwudziestego wieku. Choć sam Lange starannie owe pokrewieństwo ukrywał, przekonując, że wymyślona przezeń utopia obywa się bez techniki ${ }^{28}$, to nietrudno spostrzec, że szereg wymyślonych przez niego wynalazków zrodzonych jest z ducha mitologii i ambicji epoki. Podbój przestrzeni, szybkie i bezpieczne pojazdy, uniwersalny sposób komunikacji, panowanie nad przyrodą to aspekty, które w różnych konfiguracjach i ze zmiennym natężeniem przewijają się przez wszystkie utopijne teksty tego czasu. Ich twórcy prześcigali się w różnorodnych pomysłach, którym patronowało milczące przekonanie, że wraz z ewolucją techniki kształtować będzie się coraz doskonalsze społeczeństwo.

W Mirandzie próg między ,epoką zamętu” a ,początkiem nowej ery” ${ }^{29}$ przekroczony został nie dzięki wynalazkom, lecz za sprawą duchowej transformacji człowieka. W ujęciu takim wyraźnie dochodził do głosu polemiczny potencjał powieści, podważającej optymizm, jaki tchnął ze scjentystycznych prognoz i futurologicznych wizji rozsianych w literaturze tego czasu. Choć pomysły Langego wykazywały spore pokrewieństwa z dziewiętnastowiecznym spirytualizmem i dalekowschodnią filozofią, to ich rdzeń osadzony został wewnątrz tej samej ramy dyskursywnej, jaka wyznaczała pole refleksji „nowoczesnych alchemików". Dokonujące się w tym czasie odkrycia były dla nich nie tyle kolejnymi krokami na drodze ku coraz doskonalszej cywilizacji, co raczej zdobyczami odsłaniającymi istnienie duchowych wymiarów, wobec których nauka pozostawała bezradna. Metafizyczne horyzonty, jakie otwierały się za sprawą jej kolejnych osiągnięć, zachęcały do tworzenia wizji dyktowanych wiarą w istnienie trans-

28 „Nirwidum” - pisał Lange - „umożliwia mieszkańcom Città del Sole utrwalenie zmaterializowanych duchów oraz doprowadza ich technikę do bezwzględnego panowania nad naturą - tak, iż dzięki swej wiedzy - ludzie ci obywają się bez maszyn". A. Lan ge, Przedmowa..., op. cit., s. 7.

${ }^{29}$ A. Lange, Miranda, op. cit., s. 91. 
cendentalnego ładu. To właśnie na tym gruncie wyrosła stworzona w Mirandzie koncepcja „człowieka astralnego”, który pozbawiony był obciążeń i ograniczeń, jakie wiązały się z cielesnym aspektem istnienia. Podczas „transmutacji” dochodziło do wytrącenia wszystkich atawistycznych popędów i egoistycznych pragnień, co pozwalało na stworzenie bytu nieporównywalnie bardziej szlachetnego. Specyfika tego procesu przywodzi na myśl eksperymenty dokonywane ówcześnie w laboratoriach z tą różnicą, że o ile fizycy i chemicy przekształcali właściwości pierwiastków, o tyle mędrcy z Miasta Słońca z powodzeniem eliminowali z natury ludzkiej zło.

„Alchemia i utopia [...] spotykają się w marzeniu o transmutacji; pierwsza uderza w to, co nieredukowalne w naturze, druga w to, co nieredukowalne w historii" ${ }^{30}$, stwierdzał Emil Cioran, krytykując fundamenty, na których wsparte były marzenia przyświecające wizjom idealnych społeczeństw. W Mirandzie owe ograniczenia - przynajmniej na pozór - zostają przekroczone, bowiem sukcesy pomyślnie przeprowadzonej transmutacji otworzyły drogę do wydźwignięcia zrębów społeczności doskonałej. Ale unieważnienie tych problemów nasuwało szereg kolejnych rozterek, sprowadzających się do pytania, czy osiągnięcia te można by spożytkować do przeprowadzenia przemiany całej ludzkości.

Utopia Langego przesunięta została w stronę odmętów burzliwej historii dwudziestego wieku. W tym celu pisarz konsekwentnie rozluźnił granice doskonałego społeczeństwa, które w kanonicznych tekstach należących do tego gatunku były zazwyczaj dość szczelne. Zaznacza się to już w topografii wyspy, którą Słońcogrodzianie dzielą z państwami Telurów i Kalibanów pozostających - co sugerują same nazwy - na nieporównywalnie niższym stopniu rozwoju cywilizacyjnego. Dzieje ich sąsiedzkich konfliktów stały się pretekstem do postawienia pytania, dlaczego mieszkańcy utopii nie zdecydowali się na przemianę społeczności państw ościennych we wspólnoty ,astrali”. Otworzyło ono furtkę, przez którą do Mirandy wkroczyło szereg nowoczesnych z ducha tematów związanych z logiką rozwoju historii oraz dynamiką postępu.

Splot tych zagadnień wybrzmiał najmocniej w dyskusji między krytykami i apologetami ustroju Miasta Słońca. Pierwsi twierdzili, że realia utopii wprowadziły w stan letargu jej mieszkańców, sprawiając, że „utracili nader cenne rzeczy, mianowicie natężenie ducha, wysiłek, nieustające poczucie ryzyka i walki o byt" ${ }^{31}$. Obwiniali o taki stan rzeczy ideę transformacji człowieka w istotę astralną, twierdząc, że ów „gwałt na naturze” jest dyktowaną pośpiechem i na wskroś sztuczną próbą uzyskania tego, co powinno zostać osiągnięte na drodze długotrwałej ewolucji. Natomiast ich adwersarze przekonywali, że dzięki temu procesowi mieszkańcy Miasta Słońca przyspieszyli swój rozwój o całe tysiącle-

${ }^{30}$ E. Ci or a n, Mechanizm utopii [w:] Historia i utopia, przeł. M. Bieńczyk, Warszawa 1997, s. 74.

${ }^{31}$ A. Lange, Miranda, op. cit., s. 90. 
cia. Co więcej, zastanawiali się również, czy nie nadszedł już czas, by opanować całą wyspę i narzucić jej mieszkańcom te same rozwiązania, które tak doskonale sprawdziły się w ich społeczności.

Dramaturgia tego sporu przywodziła na myśl argumenty ówczesnych rzeczników i przeciwników modernizacji. Pytania o konsekwencje przyspieszonego tempa rozwoju, bilans wynikających z niego zysków i strat oraz spekulacje na temat przyszłości cywilizacji to węzłowe punkty dyskusji, która wraz z nadejściem lat dwudziestych poczęła zataczać coraz szersze kręgi. Jej echa pobrzmiewają w Mirandzie nawet pomimo tego, że częściowo przesłonięte zostały nawiązaniami do filozofii i tradycji Orientu. Lange nie poprzestał bynajmniej na odtworzeniu panoramy ówczesnych nadziei i niepokojów, lecz poszedł krok dalej, proponując rozstrzygnięcie konfliktu, który poróżnił mieszkańców utopii. Ponieważ toczone w jej łonie spory uznano za pierwsze objawy niewydolności ustroju, jedna z głównych bohaterek sięgnęła po środki zaradcze; zdecydowała się na ofiarę z życia, która miała na celu „odkupić grzechy i błędy swojego pokolenia” 32 . Motyw dobrowolnej śmierci i symbolicznego samooczyszczenia wspólnoty pozwolił pisarzowi na uchylenie się od przyznania racji którejkolwiek ze stron, lecz jednocześnie osłabił wymowę powieści. Zamiast rozsupłać węzeł dyskutowanych problemów w racjonalny sposób, przeciął go irracjonalnym rytuałem ${ }^{33}$.

Refleksja na temat związków między utopią a historią wykraczała w Mirandzie poza granice Miasta Słońca. Przesądziła bowiem o ukształtowaniu ramy tekstowej, wewnątrz której osadzona została opowieść Podobłocznego. Jego losy wplecione zostały w burzliwe dzieje drugiej dekady zeszłego stulecia; choć sprawami społecznymi i politycznymi interesował się w niewielkim stopniu, to przypadkowo wygłoszona prognoza na temat rychłej porażki Rosji w pierwszej wojnie światowej doprowadziła do kilkuletniego zesłania go nad jezioro Bajkał. Po abdykacji cara Mikołaja wyruszył w podróż po krajach dalekowschodnich, która - po kolizji statku z miną podwodną - zakończyła się na brzegu utopijnego państwa. Co ciekawe, lęk przed podobnym wypadkiem towarzyszył mu podczas powrotnej podróży do Europy. Wynika to w znacznej mierze z faktu, że historia stała się w Mirandzie figurą nieustannego zagrożenia; katastrofa doprowadziła do wyjścia z nurtu ówczesnych zdarzeń oraz patronowała powrotowi w ich obręb.

Przeistaczając się z „człowieka pozaczasowego” w „człowieka historycznego" Podobłoczny zaczął podzielać lęki i obawy współczesnych. Zarysowany w ten sposób kontrast między harmonią Miasta Słońca a dysonansami przepełniającymi życie Europejczyków zapisać można na rachunek tradycji utopijnej, która chętnie operowała podobnymi przeciwstawieniami. Ich integralnym elementem

32 A. Lange, Miranda, op. cit., s. 95.

${ }^{33}$ Rozwiązanie to sprawiło, że Miranda, w przeciwieństwie do kanonicznych utopii przełomu XIX i XX wieku, jest tekstem o zdecydowanie mniej wieloznacznej wymowie. Zob. na ten temat R. T. Widdicombe, Eutopia, Dystopia, Aporia: The Obstruction of Meaning in Fin-de-Siècle Utopian Texts, „Utopia Studies” 1990, vol. 1, s. 93-99. 
była strategia ironiczna, sugerująca fikcyjny charakter światów powołanych do życia przez wyobraźnię utopisty. Jednak w Mirandzie została ona zaburzona; po powrocie do Europy Podobłoczny dowiedział się, że mieszkający w Paryżu polski naukowiec Paracels Nirwid pracował nad wynalazkiem identycznym do tego, jaki udało się stworzyć mędrcom z Miasta Słońca. Niestety jeden z eksperymentów zakończył się wybuchem, który doprowadził do jego śmierci i pogrzebał szanse na wykorzystanie potencjalnych dóbr, jakie wiązały się z produkcją Nirwidum.

Przekraczając ramy utopijnej opowieści, Lange nie porzucał utopijnych marzeń. Skupiały się one wokół badań Nirwida, który twierdził, że „materia to duch skroplony, a w końcu skamieniały; że ta materia jest to wielorakie przeobrażenie jednego i tego samego pierwiastka; że pierwiastek ten w esencji swej jest to punkt matematyczny, niematerialny; że ta istota niematerialna a zmaterializowana dąży do dematerializacji i do przetworzenia się w istotę duchową". Obserwacje te doprowadziły go do przekonania, że „rozwój bytu polega na ciągłym odwracaniu się i przetwarzaniu ducha w materię i materii w ducha - i w ostateczności cały świat - gwiazdy, planety, słońca - przetworzą się w istoty duchowe i boskie" ${ }^{34}$. Teorie te układały się w katalog założeń, jakie patronowały „,nowoczesnym alchemikom", którzy - w ślad za swoimi poprzednikami - wierzyli, że ostatecznym celem ich poszukiwań powinno stać się oczyszczenie wszelkiego bytu ${ }^{35}$.

Droga do alchemicznej utopii wiodła przez laboratoria naukowców. Dokonane tam odkrycia naprowadzały na ślad istnienia „materii pierwotnej”, która stanowiła jeden z kluczowych elementów odwiecznego marzenia o transmutacji. Badania Nirwida nie przypominały w niczym rytuałów „wiedzy tajemnej”, bowiem zostały usytuowane przez Langego w kontekście poszukiwań ówczesnych fizyków, usiłujących przeniknąć i zrozumieć budowę atomu. Pogoń za najmniejszą cząstką materii nabierała przy tym wymiaru metafizycznego, bowiem przyświecała jej wiara w istnienie odwiecznego porządku, której na próżno szukać u zafascynowanych futurologicznymi wizjami nowoczesnych utopistów. Choć Miranda pod wieloma względami stanowiła votum separatum wobec ich koncepcji, to trudno jednocześnie traktować ją jedynie jako wyraz protestu wobec dokonującego się w zawrotnym tempie procesu „odczarowania świata”. Wiele z podniesionych w niej argumentów wpisywało się co prawda w chór głosów ówczesnych krytyków modernizacji, zaniepokojonych konsekwencjami wynikającymi z nazbyt szybkiej ekspansji techniki ${ }^{36}$. $\mathrm{Z}$ drugiej jednak strony, owe troski sąsiadowały $\mathrm{z}$ równie silnymi nadziejami wyartykułowanymi w retoryce, jaką podsuwał zdobywczy duch epoki.

${ }^{34}$ A. Lange, Miranda, op. cit., s. 114.

${ }^{35}$ Por. W. Fere nc, op. cit., s. 104 i nast.

${ }^{36}$ Por. J. Jedlicki, Świat zwyrodniały. Lęki i wyroki krytyków nowoczesności, Warszawa 2000. 
„Koncept transmutacji alchemicznej jest [...] wyrazem [...] odwiecznego ludzkiego przekonania, że człowiek może oddziaływać na przemiany natury", pisał Mircea Eliade, wskazując na przesłanki tkwiące u podstaw mitu alchemicznego ${ }^{37}$. Był to $w$ jego przekonaniu mit optymistyczny, podsycany marzeniami o ulepszaniu świata oraz kuszący wizją doskonałej egzystencji (czy wręcz nieśmiertelności). Przekonania te wybrzmiewały szczególnie wyraźnie w teoriach „,nowoczesnych alchemików”, którzy wierzyli, że znaleźli nowego sprzymierzeńca w odwiecznych zmaganiach z naturą - naukę, której zdobywczy impet obalał dotychczasowe pewniki i otwierał pole do nowych doświadczeń i refleksji. O ile jednak zdeklarowani wyznawcy scjentyzmu byli skłonni widzieć w jej osiągnięciach tryumfalny pochód geniuszu ludzkiego, o tyle alchemicy chcieli dostrzec coś więcej: dowód na istnienie transcendentalnego wymiaru, o którym od dawna mówili wyznawcy koncepcji ezoterycznych. Choć z perspektywy czasu ów sojusz nie okazał się trwały, to stanowił jeden z najbardziej spektakularnych świadectw wypalania się dotychczasowego porządku symbolicznego.

W Mirandzie zbliżenie między alchemią i nauką zaowocowało koncepcją utopii. Wspierała się ona na fundamentach zupełnie różnych od tych, jakie stały się budulcem większości wizji snutych przez pisarzy nowoczesnych, lecz różnice te nie powinny przesłaniać punktów wspólnych, które wraz z upływem czasu stawały się coraz bardziej widoczne. W swojej powieści - co prawda w innych dekoracjach i w dalekowschodnim kostiumie - Lange snuł te same marzenia, jakie przenikały dużą część ówczesnej kultury, owładniętej obsesją poprawiania świata i rywalizacji z naturą.

\section{Aleksander Wójtowicz}

\section{A TRANSMUTATION OF UTOPIA: 'MODERN ALCHEMY' AND SCIENCE IN ANTONI LANGE'S MIRANDA}

Sum mary

Published in 1924, Miranda is a utopian novel, saturated with modern debates about the nature of progress. Antoni Lange's project of a perfect society presented in Miranda runs counter to the view shared by the majority of writers of utopian fiction that science and new technologies should be the foundations of an ideal society. He believes that the society of the future should be founded on a marriage of scientific progress and the occult. While science would bring into this alliance the discovery of the smallest particle of matter, esotericism would contribute its understanding of the characteristics of such a particle, analogous to the alchemical prima materia. Lange's insistence on the union of the incompatible discourses of science and occultism situates his utopia in the sphere of Modern Alchemy.

${ }^{37}$ M. Eli a de, Alchemia azjatycka, przeł. I. Kania, s. 112 i nast. 